\title{
Sindrom metabolik pada remaja obes: prevalensi dan hubungannya dengan kualitas diet
}

Metabolic syndrome on obese adolescents: prevalence and its relationship with diet quality

Fillah Fithra Dieny ${ }^{1}$, Nurmasari Widyastuti ${ }^{1}$, Deny Yudi Fitranti ${ }^{1}$

${ }^{1}$ Departemen Ilmu Gizi, Fakultas Kedokteran Universitas Diponegoro Semarang

\begin{abstract}
Background: The increasing prevalence of adolescents obesity in the last decade have an impact on the increased prevalence of adolescents metabolic syndrome (MetS). Diet quality is one of the determining factors in the incidence of adolescents obesity, so it can also be a factor for MetS. Objective: To analyze the relationship between diet quality and MetS risk factors in obese adolescents. Method: A cross-sectional study was conducted on the 57 obese students in $7^{\text {th }}$ and $8^{\text {th }}$ grades of Nasima and Kesatrian Junior High School in Semarang. Blood pressure (BP) and waist circumference (WC) measurements, as well as blood samples for measurement of fasting blood glucose ( $F B G)$, triglyceride (TG) and HDL cholesterol ( $H D L-C)$ were conducted to determine the number of risk factors experienced by the subject. Diet quality was measured through assessment of food consumption using a food frequency questionnaire (FFQ). Pearson and Spearman's test was used to determine the correlation between diet quality and MetS risk factors. Results: The majority of obese adolescents (96.5\%) had a low-quality of diet. There were $31.6 \%$ subjects experienced pre-metabolic syndrome and $68.4 \%$ had MetS, with the prevalence of MetS was higher in male subjects. The diet quality, variety, adequacy scores and fiber intake of pre-metabolic syndrome group were higher than MetS group. Variety and adequacy scores had significant negative correlation with TG $(r=-0.374$, $p=0.004 ; r=-0.357, p=0.006$, respectively). There was no significant relationship between diet quality score and the number of MetS risk factors $(p=0.538)$, although they had negative correlation $(r=-0.083)$. Conclusion: Prevalence of pre-metabolic syndrome and Met $S$ was $31.6 \%$ and $68.4 \%$. Though there was no significant relationship, diet quality had a negative correlation with the number of MetS risk factors. Variety and adequacy scores had significant relationship with triglyceride levels.
\end{abstract}

KEY WORDS: diet quality; metabolic syndrome; obese adolescents

\begin{abstract}
Latar belakang: Prevalensi obesitas remaja meningkat pada dekade terakhir. Hal tersebut berdampak pada peningkatan prevalensi sindrom metabolik (SM) remaja. Kualitas diet merupakan salah satu faktor penentu dalam kejadian obesitas remaja sehingga dapat pula menjadi faktor yang berhubungan dengan sindrom metabolik. Tujuan: Menganalisis hubungan antara kualitas diet dengan faktor risiko sindrom metabolik pada remaja obesitas. Metode: Penelitian cross-sectional dilakukan pada 57 murid kelas VII dan VIII di SMP Nasima dan Kesatrian Kota Semarang yang mengalami obesitas. Pengukuran tekanan darah (TD) dan lingkar pinggang (LP), serta pengambilan sampel darah untuk pengukuran kadar glukosa darah puasa (GDP), trigliserida (TG), dan kolesterol HDL (HDL-C) dilakukan untuk menentukan jumlah faktor risiko yang dialami subjek. Kualitas diet diukur melalui penilaian konsumsi makanan dengan menggunakan formulir food frequency questionnaire (FFQ). Uji Pearson dan Spearman digunakan untuk mengetahui hubungan korelatif antara kualitas diet dengan faktor risiko SM. Hasil: Mayoritas remaja obes $(96,5 \%)$ memiliki kualitas diet rendah. Sebanyak 31,6\% subjek mengalami pra-sindrom metabolik dan 68,4\% mengalami sindrom metabolik, dengan prevalensi SM yang lebih tinggi pada subjek laki-laki. Kelompok pra-sindrom metabolik memiliki skor kualitas diet, variasi, kecukupan, dan asupan serat yang lebih tinggi daripada kelompok sindrom metabolik. Skor variasi dan kecukupan memiliki korelasi negatif yang bermakna dengan $\mathrm{TG}(\mathrm{r}=-0,374 ; \mathrm{p}=0,004$; dan $\mathrm{r}=-0,357 ; \mathrm{p}=0,006$, masing-masing untuk skor variasi dan kecukupan). Tidak terdapat hubungan bermakna antara skor kualitas diet dan jumlah faktor risiko SM ( $\mathrm{p}=0,538)$, meskipun terdapat korelasi negatif di antara keduanya $(\mathrm{r}=-0,083)$. Simpulan: Prevalensi pra-sindrom metabolik dan sindrom metabolik sebesar 31,6\% dan $68,4 \%$. Meskipun tidak terdapat hubungan yang bermakna, kualitas diet memiliki korelasi negatif dengan jumlah faktor risiko sindrom metabolik. Skor variasi dan kecukupan memiliki hubungan bermakna dengan kadar trigliserida.
\end{abstract}

KATA KUNCI: kualitas diet; sindrom metabolik; remaja obesitas

Korespondensi: Fillah Fithra Dieny, Departemen Ilmu Gizi, Fakultas Kedokteran Universitas Diponegoro Semarang, Jl. Dr.Sutomo No.18, Semarang, Jawa Tengah, Indonesia,e-mail: fillahdieny@gmail.com 


\section{PENDAHULUAN}

Masa remaja merupakan salah satu periode tumbuh kembang yang penting dan menentukan untuk periode perkembangan berikutnya. Remaja yang mengalami obesitas, kelak pada masa dewasa cenderung obesitas. Hal ini telah dibuktikan dengan adanya peningkatan insiden obesitas pada periode transisi antara remaja dan dewasa muda dalam kurun waktu lima tahun, yaitu dari 10,9\% menjadi $22,1 \%$ dan $4,3 \%$ diantaranya mempunyai indeks massa tubuh (IMT) lebih dari $40 \mathrm{~kg} / \mathrm{m}^{2}$ (1).

Prevalensi obesitas pada remaja ternyata juga meningkat pada dekade terakhir. Menurut survey kesehatan dan status gizi nasional di Amerika Serikat (National Health and Nutrition Examination Survey III/ NHANES III) tahun 1988-1994 dan 1999-2000 terjadi peningkatan remaja obesitas sebesar $11 \%$. Sementara di Indonesia, data dari Riskesdas 2013 menunjukkan prevalensi remaja gemuk usia 16-18 tahun meningkat dari 1,4\% pada tahun 2007 menjadi 7,3\% pada tahun 2013 yang terdiri dari 5,7\% overweight dan 1,6\% obesitas (2). Di Jawa Tengah, prevalensi obesitas pada remaja dengan usia di atas 15 tahun sebesar 17\% dan lebih banyak terjadi pada perempuan $(21,7 \%)$ dibandingkan laki-laki $(11,5 \%)(3)$.

Obesitas berkaitan erat dengan sindrom metabolik (SM) karena merupakan salah satu dari sekumpulan kelainan metabolik yang terjadi pada penderita sindrom metabolik. Sindrom metabolik didefinisikan sebagai kelompok faktor risiko penyakit jantung koroner dan penyakit metabolik seperti diabetes mellitus (DM) tipe 2 dan aterosklerosis. Tren peningkatan angka kejadian obesitas pada kelompok usia remaja berakibat pada peningkatan angka kejadian SM. Laporan dari National Health and Nutrition Examination Survey III (NHANES III) menunjukkan peningkatan prevalensi SM remaja berdasarkan kriteria NCEP-ATP III (National Cholesterol Education Program - Adult Treatment Panel III) dari periode 1988-1994 ke periode 1999-2000 yaitu 4,2\% menjadi 6,4\% (4). Survei kesehatan dan status gizi nasional di Amerika Serikat (National Health and Nutrition Examination Survey III/NHANES III) tahun 1988-1994 memperlihatkan bahwa sindrom metabolik terjadi pada 4,2\% remaja usia 12-19 tahun dan $28,7 \%$ remaja obesitas menderita sindrom metabolik (5).
Penyebab obesitas sebagai komponen SM sangatlah kompleks dan multifaktor, meliputi faktor genetik, sosial ekonomi, lingkungan, metabolik, kebudayaan, dan lainnya. Individu dengan obesitas sentral lebih berisiko mengalami sindrom metabolik dibandingkan obesitas perifer (6). Obesitas umumnya disebabkan karena masukan energi melebihi penggunaan energi oleh tubuh untuk metabolisme basal, aktivitas fisik, specific dynamic action, dan pertumbuhan (7). Kelebihan energi yang dikonsumsi tanpa disertai penggunaan energi yang memadai akan menyebabkan peningkatan penyimpanan energi dalam sel lemak yang berakibat meningkatnya jumlah dan ukuran sel lemak sehingga mengakibatkan obesitas (8).

Asupan makan merupakan salah satu faktor penentu terjadinya obesitas pada remaja, yang selanjutnya dapat pula mempengaruhi kejadian sindrom metabolik. Asupan zat gizi pada remaja obesitas ditemukan melebihi anjuran kebutuhannya. Sebagian besar kelompok obesitas memiliki tingkat konsumsi energi, karbohidrat, protein, dan lemak yang lebih tinggi daripada kelompok non obesitas. Bahkan pada tingkat konsumsi lemak, 90\% kelompok obesitas memiliki tingkat konsumsi yang berlebih. Sebagian besar kelompok obesitas juga memiliki frekuensi konsumsi pangan, makanan cepat saji, dan kudapan lebih tinggi daripada kelompok non obesitas (9). Konsumsi makanan cepat saji berkaitan dengan masalah obesitas karena makanan cepat saji cenderung padat energi, rendah mikronutrien, rendah serat sehingga berkontribusi terhadap gizi lebih dan obesitas (10).

Obesitas juga ditandai dengan konsumsi gula dan minuman soda yang berlebihan (11). Hal tersebut didukung oleh hasil penelitian di Amerika, bahwa minuman soda merupakan sumber utama gula yang terdapat pada minuman dan jumlahnya melebihi rekomendasi total konsumsi gula untuk remaja. Peningkatan konsumsi minuman soda berkorelasi positif dengan peningkatan konsumsi gula dan kejadian obesitas secara bersamaan. Ketidaksesuaian pemenuhan zat gizi berdasarkan rekomendasi diet dapat berpengaruh terhadap kualitas diet (12). Kualitas diet dapat menentukan asupan makan telah sesuai rekomendasi atau tidak, serta akan mempengaruhi status gizi. Kualitas diet yang rendah akan berdampak pada peningkatan IMT yang ditandai dengan konsumsi 
energi, gula, dan lemak jenuh secara berlebih, tetapi rendah konsumsi padi-padian, buah, dan sayur seperti yang tampak pada remaja obes $(13,14)$. Sementara kualitas diet yang bagus berkaitan dengan tingginya konsumsi makanan dengan densitas energi rendah seperti buah dan sayur, serta mencukupi kebutuhan makronutrien secara tepat, tidak kurang maupun berlebih (15). Kualitas diet yang rendah pada remaja obes diperkirakan dapat pula mempengaruhi terjadinya sindrom metabolik pada remaja obes. Berdasarkan latar belakang tersebut, peneliti ingin menganalisis hubungan antara kualitas diet dengan faktor risiko sindrom metabolik pada remaja obes.

\section{BAHAN DAN METODE}

Penelitian ini merupakan penelitian observasional dengan desain cross-sectional yang dilakukan pada bulan April - Mei 2015. Populasi target pada penelitian ini adalah seluruh remaja di Semarang. Sementara populasi terjangkau adalah siswa dan siswi kelas VII dan VIII di SMP Nasima dan Kesatrian Kota Semarang. Besar sampel untuk penelitian ini ditentukan dengan menggunakan rumus besar sampel penelitian observasional pada satu populasi dan diperoleh hasil sebanyak 50 siswa. Cara pemilihan sampel atau metode sampling dilakukan dengan cara consecutive sampling. Subjek yang merupakan siswa dan siswi kelas VII dan VIII usia 13-15 tahun diskrining berdasarkan indeks massa tubuh berdasarkan usia (IMT/U). Berat badan diukur menggunakan timbangan digital dengan ketelitian $0,1 \mathrm{~kg}$ dan tinggi badan diukur menggunakan microtoise dengan ketelitian $0,1 \mathrm{~cm}$. Kriteria inklusi pada penelitian ini adalah subjek memiliki status gizi obesitas (Z score IMT/U > 2 SD menurut WHO 2005) (16); tidak sedang menjalani diet karena penyakit tertentu, seperti hipertensi, diabetes mellitus; dan bersedia mengikuti penelitian dengan mengisi formulir informed consent. Kriteria eksklusi pada penelitian ini yaitu subjek absen atau sakit selama penelitian. Berdasarkan kriteria inklusi dan eksklusi didapatkan jumlah sampel sebanyak 57 subjek, yang terdiri dari 31 perempuan dan 26 laki-laki.

Variabel terikat pada penelitian ini adalah sindrom metabolik beserta beberapa komponennya. Sindrom metabolik merupakan sekumpulan kelainan metabolik yang ditandai dengan beberapa komponen, yaitu tekanan darah, kadar glukosa darah, dan trigliserida yang melebihi normal, kadar kolesterol high-density lipoprotein (HDL) yang rendah, serta adanya obesitas sentral. Variabel bebas pada penelitian ini adalah kualitas diet. Tekanan darah diukur menggunakan tensimeter omron digital dalam satuan $\mathrm{mmHg}$. Kadar trigliserida serum diukur melalui uji enzimatik kolorimetri menggunakan glycerol phosphate oxidase (GPO), dalam satuan mg/dl. Kadar glukosa darah puasa diukur menggunakan spektrofotometri dengan metode glucose oxidase (GOD), dalam satuan mg/dL. Kadar kolesterol HDL diukur dengan metode CHODPAP, dalam satuan mg/dL. Pengambilan sampel darah untuk pengukuran kadar trigliserida, glukosa darah puasa (GDP), dan kolesterol HDL dilaksanakan pada subjek yang telah berpuasa selama 10 jam. Lingkar pinggang diperoleh dari hasil pengukuran panjang lingkar daerah antara tulang rusuk dengan puncak iliak melewati pusar/ umbilikus, diukur dengan pita ukur berkapasitas $150 \mathrm{~cm}$ dengan ketelitian $0,1 \mathrm{~cm}$, dalam satuan $\mathrm{cm}$.

Kualitas diet diukur dengan cara menilai konsumsi makanan menggunakan formulir food frequency questionnaire (FFQ), yang kemudian dihitung skor kualitas dietnya menggunakan formulir Diet Quality Indexs International (DQI-I) (17). Skor untuk masingmasing kategori (variasi, kecukupan, moderasi, keseimbangan keseluruhan) dijumlahkan, kemudian skor dari seluruh kategori ditotal sehingga total DQI-I bisa bervariasi mulai dari 0 sampai 100 (0 adalah skor terendah dan 100 merupakan skor tertinggi). Kualitas diet dianggap rendah apabila total skor $\leq 60 \%$ dari skor sempurna dan apabila skor $>60 \%$ dari skor sempurna maka kualitas dietnya tinggi $(17,18)$.

Hasil pengukuran tekanan darah, kadar trigliserida, GDP, kolesterol HDL, dan lingkar pinggang pada subjek digunakan untuk mengklasifikasikan subjek menderita sindrom metabolik atau tidak. Sindrom metabolik terjadi apabila terdapat minimal tiga dari lima faktor risiko yaitu obesitas abdominal (lingkar pinggang $\geq$ persentil 90, untuk laki-laki maupun perempuan); tekanan darah $\geq$ persentil 90, untuk laki-laki maupun perempuan; kadar kolesterol HDL $\leq 40 \mathrm{mg} / \mathrm{dl}$; kadar trigliserida darah $\geq 110 \mathrm{mg} / \mathrm{dl}$; dan kadar GDP $\geq 110 \mathrm{mg} / \mathrm{dl}$ (19). Jika subjek memiliki 1 sampai 2 faktor risiko, maka subjek diklasifikasikan kelompok pra-sindrom metabolik. 
Hasil penelitian disajikan dalam tabel distribusi frekuensi. Data numerik disajikan dalam bentuk rerata, standar deviasi, nilai maksimum, dan nilai minimum sedangkan data kategorik disajikan dalam bentuk persentase. Uji Pearson dan Spearman digunakan untuk menganalisis korelasi antara skor setiap kategori kualitas diet dengan setiap faktor risiko sindrom metabolik. Selanjutnya, dilakukan uji Spearman untuk menganalisis korelasi skor kualitas diet dengan jumlah faktor risiko sindrom metabolik.

\section{HASIL}

\section{Gambaran asupan makan dan kualitas diet remaja}

Hasil penilaian kualitas diet menggambarkan asupan makan subjek dan beberapa komponen kualitas diet seperti variasi, kecukupan, moderasi, dan keseimbangan keseluruhan (Tabel 1).

Data asupan makanan pada Tabel 1 menunjukkan skor kualitas diet subjek berkisar antara 32-63 dengan rerata 48,04 \pm ,82 yang berarti kualitas diet pada subjek cenderung rendah. Hasil skor variasi makanan pada subjek menunjukkan rentang skor yang cukup jauh yaitu 3-20 dengan rerata $15,18 \pm 4,19$. Rentang skor variasi yang cukup jauh tersebut dipengaruhi oleh perbedaan jumlah kelompok makanan dan jenis sumber protein yang dikonsumsi oleh subjek. Nilai rerata skor kecukupan memperlihatkan bahwa rata-rata subjek belum memenuhi kecukupan asupan harian sesuai yang direkomendasikan. Data rerata asupan serat, zat besi, dan kalsium pada subjek termasuk dalam kriteria rendah karena tidak memenuhi jumlah angka kecukupan

Tabel 1. Nilai rerata, standar deviasi, minimum, dan maksimum data kebiasaan makan pada subjek

\begin{tabular}{|c|c|c|c|}
\hline Data kualitas diet & Rerata \pm SD & Minimum & Maksimum \\
\hline Kualitas diet (skor) & $48,04 \pm 7,82$ & 32 & 63 \\
\hline Variasi (skor) & $15,18 \pm 4,19$ & 3 & 20 \\
\hline $\begin{array}{l}\text { Semua kelompok makanan } \\
\text { (kelompok makanan/hari) }\end{array}$ & $3,84 \pm 1,05$ & 1 & 5 \\
\hline Sumber protein (jenis/hari) & $2,47 \pm 0,95$ & 0,00 & 4,00 \\
\hline Kecukupan (skor) & $24,10 \pm 5,48$ & 14,00 & 34,00 \\
\hline Kelompok sayuran (porsi/hari) & $1,00 \pm 0,78$ & 0,10 & 3,40 \\
\hline Kelompok buah (porsi/hari) & $1,42 \pm 1,13$ & 0,10 & 6,00 \\
\hline Kelompok makanan pokok (porsi/hari) & $5,60 \pm 1,49$ & 2,50 & 8,00 \\
\hline Asupan serat (g/ hari) & $13,16 \pm 4,19$ & 5,10 & 22,90 \\
\hline Serat larut (g/ hari) & $0,68 \pm 0,69$ & 0,00 & 4,70 \\
\hline Serat tidak larut (g/ hari) & $1,36 \pm 1,09$ & 0,00 & 4,80 \\
\hline Protein (g/hari) & $86,66 \pm 24,09$ & 43,70 & 163,50 \\
\hline Zat besi (mg/hari) & $12,51 \pm 5,52$ & 4,90 & 39,50 \\
\hline Kalsium (g/hari) & $547,37 \pm 262,45$ & 169,70 & 1520,10 \\
\hline Vitamin C (mg/hari) & $97,99 \pm 54,75$ & 19,90 & 228,00 \\
\hline Moderasi & $8,74 \pm 4,64$ & 0 & 28,00 \\
\hline Total lemak (g/hari) & $96,43 \pm 20,73$ & 60,20 & 166,40 \\
\hline Lemak jenuh (g/hari) & $46,29 \pm 11,34$ & 22,70 & 82,80 \\
\hline Kolesterol (g/hari) & $380,45 \pm 160,22$ & 107,20 & 947,90 \\
\hline Natrium (mg/hari) & $1393,95 \pm 749,49$ & 339,80 & 2956,40 \\
\hline Makanan rendah zat gizi & $15,27 \pm 3,30$ & 5,70 & 28,50 \\
\hline Keseimbangan keseluruhan & $0,35 \pm 0,77$ & 0 & 2,00 \\
\hline Makronutrien & $0,24 \pm 0,66$ & 0 & 2,00 \\
\hline Asam lemak & $0,07 \pm 0,37$ & 0 & 2,00 \\
\hline PUFA $^{1}$ (g/hari) & $17,73 \pm 5,18$ & 8,00 & 32,10 \\
\hline MUFA $^{2}$ (g/hari) & $25,80 \pm 7,53$ & 13,70 & 51,30 \\
\hline Karbohidrat (g/hari) & $324,69 \pm 49,38$ & 216,40 & 443,10 \\
\hline Total energi (Kcal/hari) & $2493,41 \pm 379,86$ & 1579,50 & 3471,30 \\
\hline
\end{tabular}

${ }^{1} \mathrm{PUFA}=$ polyunsaturated fatty acids $;{ }^{2} \mathrm{MUFA}=$ monounsaturated fatty acid 
gizi (AKG) tahun 2013 pada remaja usia 13-15 tahun (20). Berlainan dengan hasil tersebut, nilai rerata asupan protein dan vitamin $\mathrm{C}$ subjek sudah sesuai dengan jumlah rekomendasi asupan harian. Sementara itu, skor moderasi digunakan untuk mengevaluasi asupan makanan dan zat gizi yang berhubungan dengan penyakit kronis dan perlu dibatasi. Rerata skor moderasi yang rendah mengindikasikan adanya kecenderungan subjek untuk mengkonsumsi makanan yang rendah zat gizi secara berlebihan serta konsumsi lemak total, lemak jenuh, kolesterol, dan natrium yang juga berlebih. Komponen yang terakhir dalam kualitas diet adalah keseimbangan keseluruhan. Skor keseimbangan keseluruhan akan menunjukkan keseimbangan keseluruhan diet seseorang dalam hal proporsionalitas antara sumbersumber energi dan komposisi asam lemak. Rerata yang rendah pada skor keseimbangan keseluruhan subjek mencerminkan ketidakseimbangan diet, yaitu konsumsi makanan subjek sehari-hari memiliki proposi yang kurang seimbang pada kelompok sumber energi dan komposisi asam lemak. Hal tersebut antara lain dapat dilihat pada data asupan lemak dan kolesterol subjek, yang menunjukkan tingginya nilai rerata asupan lemak dan kolesterol yaitu

Tabel 2. Gambaran kategori asupan makanan subjek berdasarkan jenis kelamin

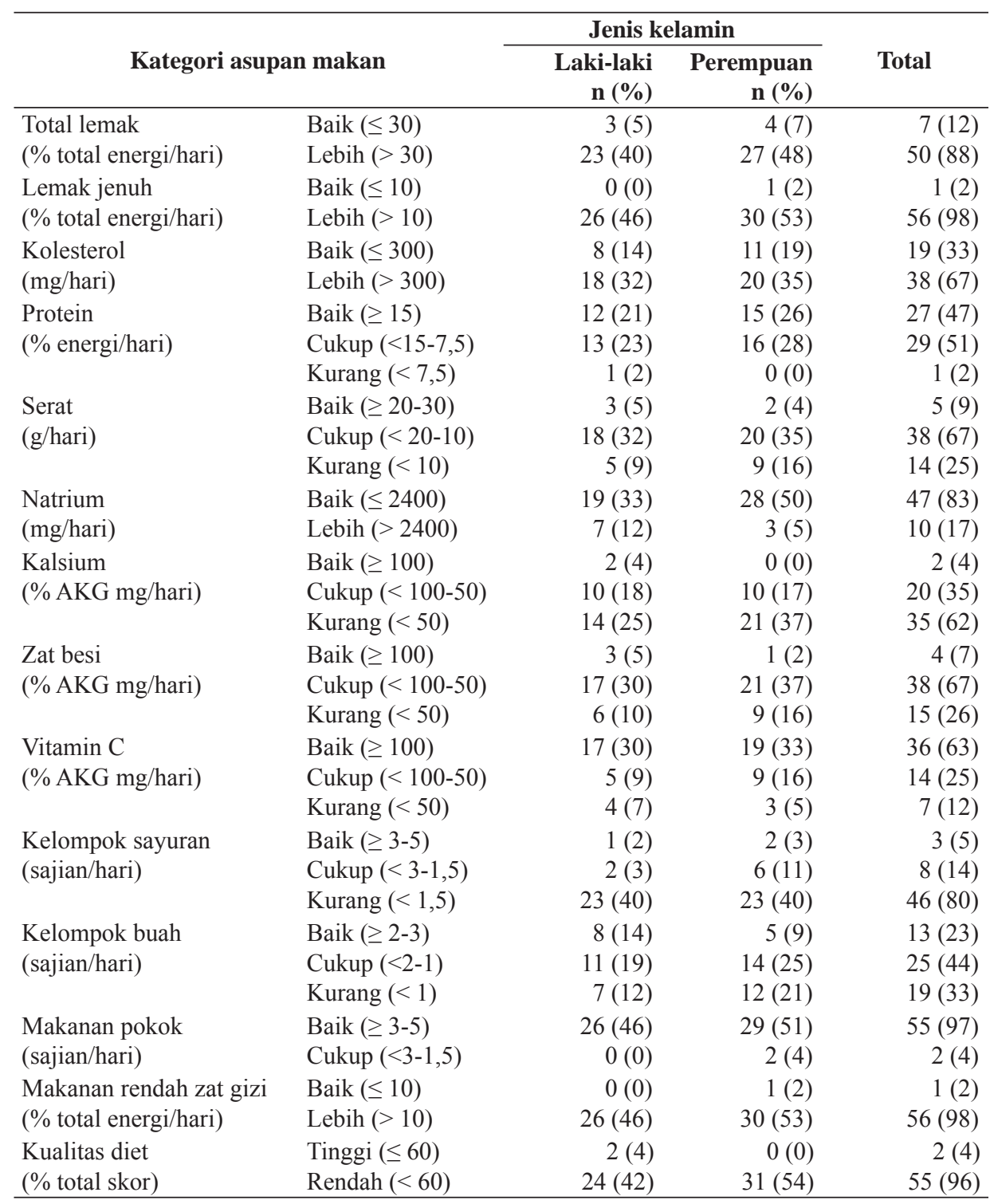


Tabel 3. Nilai rerata, standar deviasi, minimum, dan maksimum data tekanan darah, kadar trigliserida, kadar glukosa darah puasa, kadar kolesterol HDL, dan lingkar pinggang berdasarkan jenis kelamin

\begin{tabular}{lrrrrrr}
\hline \multirow{2}{*}{$\begin{array}{c}\text { Komponen sindrom } \\
\text { metabolik }\end{array}$} & \multicolumn{2}{c}{ Laki-laki } & \multicolumn{2}{c}{ Perempuan } \\
\cline { 2 - 6 } & Rerata \pm SD & Min & Maks & Rerata \pm SD & Min & Maks \\
\hline $\mathrm{TD}^{1}$ sistolik (mmHg) & $125,19 \pm 10,15$ & 110 & 140 & $122,74 \pm 10,07$ & 105 & 145 \\
$\mathrm{TD}$ diastolik $(\mathrm{mmHg})$ & $77,88 \pm 7,37$ & 60 & 90 & $80,65 \pm 6,42$ & 65 & 95 \\
Trigliserida (mg/dL) & $157,42 \pm 74,76$ & 62 & 330 & $136,00 \pm 42,14$ & 67 & 226 \\
$\mathrm{GDP}^{2}(\mathrm{mg} / \mathrm{dL})$ & $98,19 \pm 13,44$ & 64 & 132 & $91,45 \pm 8,52$ & 75 & 111 \\
$\mathrm{HDL}^{3}(\mathrm{mg} / \mathrm{dL})$ & $37,00 \pm 6,83$ & 26 & 58 & $39,03 \pm 5,84$ & 28 & 53 \\
$\mathrm{LP}^{4}(\mathrm{~cm})$ & $96,94 \pm 7,73$ & 84 & 110 & $89,11 \pm 5,87$ & 77 & 103 \\
\hline
\end{tabular}

${ }^{1} \mathrm{TD}=$ tekanan darah; ${ }^{2} \mathrm{GDP}=$ glukosa darah puasa; ${ }^{3} \mathrm{HDL}=$ high-density lipoprotein $;{ }^{4} \mathrm{LP}=$ lingkar pinggang

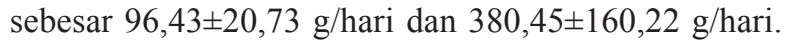
Akan tetapi, rerata jumlah asupan harian karbohidrat dan natrium pada subjek penelitian ini sudah sesuai dengan jumlah rekomendasi asupan harian. Namun, nilai maksimum asupan natrium menunjukkan bahwa terdapat subjek yang memiliki jumlah asupan natrium melebihi rekomendasi (asupan rekomendasi $1500 \mathrm{mg}$ /hari).

Persentase subjek pada beberapa kategori asupan makanan memperlihatkan adanya pola kebiasaan konsumsi makanan yang kurang baik pada remaja. Tingginya persentase subjek pada kategori total lemak, lemak jenuh, kolesterol, dan makanan rendah zat gizi yang berlebih menunjukkan bahwa remaja mengkonsumsi makanan dengan zat gizi yang tidak seimbang, yaitu densitas zat gizi rendah dan tinggi lemak. Selain itu, subjek juga memiliki asupan kalsium dan sayuran yang kurang memenuhi kebutuhan sehari-hari. Namun, terdapat pula beberapa kategori asupan makan yang sudah cukup memenuhi kebutuhan atau sudah baik, diantaranya yaitu asupan zat besi, vitamin C, buah-buahan, dan makanan pokok. Sejalan dengan hasil tersebut, penilaian kualitas diet pada subjek menunjukkan bahwa secara keseluruhan mayoritas subjek memiliki kualitas diet rendah. Artinya, asupan makan keseharian kurang bervariasi dan berlebih, yang secara keseluruhan menunjukkan bahwa tidak sesuai dengan gizi seimbang (Tabel 2).

\section{Gambaran faktor risiko dan kejadian sindrom me- tabolik pada remaja obes}

Menurut NCEP-ATP III, kejadian sindrom metabolik pada individu dapat dianalisis dari lima faktor risiko meliputi tekanan darah, kadar trigliserida, glukosa darah puasa, kolesterol HDL, dan lingkar pinggang. Data dari Tabel 3 menunjukkan bahwa rerata tekanan darah sistol dan diastol, serta kadar kolesterol HDL pada subjek perempuan dan laki-laki tidak jauh berbeda. Namun, laki-laki memiliki kadar HDL yang lebih rendah daripada perempuan. Sementara itu, nilai rerata dan maksimum kadar GDP dan trigliserida pada subjek laki-laki lebih tinggi dibandingkan dengan subjek perempuan. Hal tersebut menunjukkan bahwa laki-laki memiliki kecenderungan yang lebih besar mengalami sindrom metabolik. Sementara itu, data lingkar pinggang menunjukkan bahwa laki-laki dan perempuan sama-sama memiliki rerata lingkar pinggang yang termasuk dalam kategori obesitas abdominal.

Data nilai masing-masing komponen sindrom metabolik dikategorikan untuk mengetahui gambaran distribusi laki-laki dan perempuan pada tiap-tiap kategori. Berdasarkan Tabel 4, mayoritas subjek laki-laki dan perempuan memiliki tekanan darah (29,8\% laki-laki dan $31,6 \%$ perempuan); kadar trigliserida (31,6\% laki-laki dan $40,4 \%$ perempuan); dan lingkar pinggang (38,6\% laki-laki dan 52,6\% perempuan) yang termasuk dalam kategori tinggi. Berlainan dengan beberapa komponen sebelumnya, data kadar GDP menunjukkan bahwa $38,6 \%$ subjek laki-laki dan 52,6\% subjek perempuan termasuk dalam kategori normal. Sementara itu, 34 subjek memiliki kadar kolesterol HDL yang rendah, yaitu sebesar masing-masing $29,8 \%$ baik pada subjek laki-laki maupun perempuan.

Hasil penelitian menunjukkan bahwa seluruh subjek telah memiliki sedikitnya satu risiko sindrom metabolik. Sebagian besar subjek perempuan $(26,3 \%)$ memiliki 3 faktor risiko sindrom metabolik dan diikuti 
Tabel 4. Gambaran kategori masing-masing faktor risiko sindrom metabolik berdasarkan jenis kelamin

\begin{tabular}{lccc}
\hline \multirow{2}{*}{$\begin{array}{c}\text { Kategori komponen sindrom } \\
\text { metabolik }\end{array}$} & $\begin{array}{c}\text { Jenis kelamin } \\
\text { Laki-laki } \\
\text { n (\%) }\end{array}$ & $\begin{array}{c}\text { Perempuan } \\
\mathbf{n}(\%)\end{array}$ & Total \\
\hline Tekanan darah & & & \\
$\quad$ Normal & $9(15,8)$ & $13(22,8)$ & $22(38,6)$ \\
$\quad$ Tinggi $(\geq 90$ persentil) & $17(29,8)$ & $18(31,6)$ & $35(61,4)$ \\
Kadar trigliserida & & & \\
$\quad$ Normal & $8(14,0)$ & $8(14,0)$ & $16(28,1)$ \\
$\quad$ Tinggi $(\geq 110 \mathrm{mg} / \mathrm{dL})$ & $18(31,6)$ & $23(40,4)$ & $41(71,9)$ \\
Kadar glukosa darah puasa & & & \\
$\quad$ Normal & $22(38,6)$ & $30(52,6)$ & $52(91,2)$ \\
$\quad$ Tinggi $(\geq 110 \mathrm{mg} / \mathrm{dL})$ & $4(7,0)$ & $1(1,8)$ & $5(8,8)$ \\
Kadar kolesterol HDL & & & \\
$\quad$ Rendah & $17(29,8)$ & $17(29,8)$ & $34(59,6)$ \\
$\quad$ Normal $(\leq 40 \mathrm{mg} / \mathrm{dL})$ & $9(15,8)$ & $14(24,6)$ & $23(40,4)$ \\
Lingkar pinggang & & & \\
$\quad$ Normal & $4(7,0)$ & $1(1,8)$ & $5(8,8)$ \\
$\quad$ Tinggi $(\geq 90$ persentil) & $22(38,6)$ & $30(52,6)$ & $52(91,2)$ \\
\hline
\end{tabular}

Tabel 5. Gambaran kejadian sindrom metabolik berdasarkan jenis kelamin subjek

\begin{tabular}{lccc}
\hline \multirow{2}{*}{$\begin{array}{c}\text { Kejadian sindrom } \\
\text { metabolik }\end{array}$} & \multicolumn{2}{c}{ Jenis kelamin } & \\
\cline { 2 - 3 } & $\begin{array}{c}\text { Laki-laki } \\
\text { n (\%) }\end{array}$ & $\begin{array}{c}\text { Perempuan } \\
\text { n (\%) }\end{array}$ & \\
\hline Pra-sindrom metabolik & $8(14)$ & $10(17)$ & $18(32)$ \\
Sindrom metabolik & $18(32)$ & $21(37)$ & $39(68)$ \\
Total & $26(46)$ & $31(54)$ & $57(100)$ \\
\hline
\end{tabular}

sebanyak $15,8 \%$ subjek perempuan memiliki 2 faktor risiko sindrom metabolik. Sementara sebagian besar laki-laki memiliki 3 faktor risiko $(15,8 \%)$ dan sebesar $14,0 \%$ subjek memiliki 4 faktor risiko sindrom metabolik. Jumlah subjek yang memiliki 5 faktor risiko hanya satu, yaitu seorang laki-laki. Berdasarkan hasil pengukuran beberapa komponen sindrom metabolik (Tabel 5) diketahui bahwa sebanyak $68,4 \%$ subjek telah mengalami sindrom metabolik dan 31,6\% mengalami pra-sindrom metabolik. Prevalensi sindrom metabolik pada subjek laki-laki $(69,2 \%)$ lebih besar daripada subjek perempuan $(67,7 \%)$. Angka prevalensi yang lebih tinggi pada subjek laki-laki dapat disebabkan nilai rerata kadar GDP dan trigliserida pada laki-laki (GDP=98 mg/dL dan TG=157 $\mathrm{mg} / \mathrm{dL}$ ) yang lebih tinggi daripada perempuan (GDP $=91$ $\mathrm{mg} / \mathrm{dL}$ dan $\mathrm{TG}=136 \mathrm{mg} / \mathrm{dL}$ ), serta kadar kolesterol HDL yang lebih rendah $(37 \mathrm{mg} / \mathrm{dL}$ dibandingkan $39 \mathrm{mg} / \mathrm{dL})$.

\section{Hubungan kualitas diet dengan kejadian sindrom metabolik}

Asupan makan memiliki pengaruh yang besar terhadap kejadian obesitas. Dengan demikian, asupan makan juga dapat berhubungan dengan kejadian sindrom metabolik, obesitas sentral menjadi salah satu komponennya. Nilai rerata skor kualitas diet dan beberapa komponennya berdasarkan kategori sindrom metabolik akan menggambarkan perbedaan nilai yang dimiliki kelompok pra-sindrom metabolik dan sindrom metabolik.

Berdasarkan Tabel 6 diketahui bahwa rerata skor kualitas diet, variasi, kecukupan, dan asupan serat pada kelompok pra-sindrom metabolik lebih tinggi dibandingkan kelompok sindrom metabolik. Hal ini menunjukkan bahwa kelompok pra-sindrom metabolik memiliki kebiasaan makan yang lebih bervariasi, memiliki tingkat kecukupan yang lebih baik terhadap rekomendasi asupan harian, serta asupan serat yang lebih baik dibandingkan kelompok sindrom metabolik. Asupan serat yang lebih tinggi pada kelompok pra-sindrom metabolik juga memperlihatkan adanya proteksi dari serat terhadap beberapa faktor sindrom metabolik.

Uji korelasi menunjukkan bahwa tidak terdapat korelasi bermakna antara skor kualitas diet dengan jumlah 
Tabel 6. Nilai rerata skor kualitas diet, variasi, kecukupan, dan asupan serat berdasarkan kategori sindrom metabolik

\begin{tabular}{lcccc}
\hline \multirow{2}{*}{\multicolumn{1}{c}{ Kategori }} & \multicolumn{4}{c}{ Rerata \pm SD } \\
\cline { 2 - 5 } & Skor kualitas diet & Skor variasi & Skor kecukupan & Asupan serat \\
\hline Pra-sindrom metabolik & $50,00 \pm 7,96$ & $16,33 \pm 4,10$ & $25,78 \pm 5,57$ & $14,53 \pm 4,55$ \\
Sindrom metabolik & $47,13 \pm 7,69$ & $14,64 \pm 4,17$ & $23,33 \pm 5,33$ & $12,52 \pm 3,91$ \\
\hline
\end{tabular}

Tabel 7. Korelasi skor komponen kualitas diet dengan nilai masing-masing faktor risiko sindrom metabolik

\begin{tabular}{lccccccc}
\hline Kualitas diet & & TD $^{\mathbf{1}}$ sistolik & TD diastolik & Trigliserida & GDP $^{2}$ & HDL $^{3}$ & LP $^{\mathbf{4}}$ \\
\hline Skor variasi & $\mathrm{r}$ & $-0,078$ & $-0,006$ & $-0,374^{* *}$ & 0,050 & 0,036 & 0,076 \\
& $\mathrm{p}$ & 0,562 & 0,965 & 0,004 & 0,714 & 0,792 & 0,574 \\
Skor kecukupan & $\mathrm{n}$ & 57 & 57 & 57 & 57 & 57 & 57 \\
& $\mathrm{r}$ & $-0,155$ & $-0,122$ & $-0,357^{* *}$ & $0,045^{\mathrm{a}}$ & $-0,105^{\mathrm{a}}$ & $0,196^{\mathrm{a}}$ \\
& $\mathrm{p}$ & 0,249 & 0,366 & 0,006 & $0,738^{\mathrm{a}}$ & $0,438^{\mathrm{a}}$ & $0,144^{\mathrm{a}}$ \\
Skor moderasi & $\mathrm{n}$ & 57 & 57 & 57 & 57 & 57 & 57 \\
& $\mathrm{r}$ & 0,081 & 0,104 & 0,062 & $-0,036$ & 0,004 & $-0,023$ \\
\multirow{2}{*}{ Skor keseimbangan } & $\mathrm{p}$ & 0,549 & 0,439 & 0,646 & 0,788 & 0,975 & 0,867 \\
keseluruhan & $\mathrm{n}$ & 57 & 57 & 57 & 57 & 57 & 57 \\
& $\mathrm{p}$ & 0,117 & 0,197 & 0,004 & $-0,102$ & $-0,034$ & $0,324^{*}$ \\
& $\mathrm{n}$ & 57 & 0,142 & 0,975 & 0,448 & 0,803 & 0,014 \\
\hline
\end{tabular}

${ }^{1} \mathrm{TD}=$ tekanan darah; ${ }^{2} \mathrm{GDP}=$ glukosa darah puasa; ${ }^{3} \mathrm{HDL}=$ high-density lipoprotein $;{ }^{4} \mathrm{LP}=$ lingkar pinggang; ${ }^{\mathrm{a}} \mathrm{Uji} \mathrm{Korelasi}$ Pearson; *signifikan $<0.05 ; *$ signifikan $<0.01$

faktor risiko sindrom metabolik yang dimiliki subjek $(\mathrm{r}=$ -0,083; $p=0,538)$. Meskipun demikian, skor kualitas diet memiliki arah korelasi yang negatif dengan jumlah faktor risiko sindrom metabolik. Artinya, semakin tinggi skor kualitas diet yang dimiliki subjek, semakin sedikit jumlah faktor risiko yang dimiliki subjek.

Hasil analisis hubungan antara skor setiap komponen kualitas diet dengan nilai masing-masing komponen sindrom metabolik disajikan pada Tabel 7. Data tersebut menunjukkan bahwa terdapat korelasi bermakna antara skor variasi dan skor kecukupan dengan kadar trigliserida (-0,374 dan -0,357), serta skor keseimbangan keseluruhan dengan lingkar pinggang. Arah korelasi negatif yang terdapat pada hubungan skor variasi dan kecukupan dengan kadar trigliserida menyatakan bahwa semakin bervariasi konsumsi makan dan semakin tercukupi kualitas diet subjek, maka kadar trigliseridanya akan semakin baik.

\section{BAHASAN}

Kejadian obesitas terutama obesitas abdominal memiliki hubungan yang erat dengan sindrom metabolik.
Berdasarkan National Cholesterol Education Program and Adult Treatment Panel III (NCEP-ATP III), seseorang dikatakan menderita sindrom metabolik jika mempunyai minimal 3 dari 5 faktor risiko yaitu obesitas abdominal, peningkatan tekanan darah, kadar GDP, dan trigliserida yang melebihi normal, serta kadar kolesterol HDL yang kurang dari nilai normal. Tren peningkatan prevalensi sindrom metabolik pada individu yang mengalami obesitas tidak hanya terjadi pada kelompok usia dewasa, tetapi juga pada kelompok usia remaja. Hasil penelitian ini menyatakan bahwa dari 57 orang remaja obes, sebanyak $68,4 \%$ telah mengalami sindrom metabolik sedangkan 31,6\% mengalami pra-sindrom metabolik. Subjek laki-laki $(69,2 \%)$ memiliki prevalensi sindrom metabolik yang lebih besar daripada subjek perempuan $(67,7 \%)$. Data nilai rerata, nilai minimal, dan maksimal faktor risiko pada masing-masing kelompok jenis kelamin menjelaskan alasan kecenderungan bahwa prevalensi sindrom metabolik lebih tinggi pada remaja laki-laki daripada perempuan. Hasil pada penelitian ini sesuai dengan penelitian pada remaja di US, yang menyatakan bahwa prevalensi sindrom metabolik lebih tinggi pada remaja laki-laki $(5,1 \%)$ dibandingkan remaja perempuan 
$(1,7 \%)(21)$. Penelitian tentang sindrom metabolik pada remaja di wilayah Mediterania juga menyatakan bahwa prevalensi sindrom metabolik signifikan terutama pada kelompok remaja laki-laki yang mengalami obesitas (22).

Berdasarkan hasil pemeriksaan terhadap lima faktor risiko sindrom metabolik, sebagian besar subjek memiliki tekanan darah, kadar trigliserida, dan lingkar pinggang yang termasuk dalam kategori tinggi dan kadar kolesterol HDL yang rendah. Sementara itu, mayoritas subjek memiliki kadar glukosa darah normal. Tekanan darah tinggi biasa terjadi pada remaja obes (23). Kategori lingkar pinggang tinggi yang dimiliki oleh mayoritas subjek $(91,2 \%)$ menunjukkan bahwa sebagian besar subjek mengalami obesitas abdominal. Penelitian terhadap remaja di Brazil juga menyatakan hal yang sama, yaitu obesitas abdominal menjadi faktor risiko sindrom metabolik yang paling banyak dimiliki oleh remaja (55\%) (24). Lingkar pinggang juga merupakan prediktor resistensi insulin dan hipertensi pada anak. Resistensi insulin berperan besar dalam terjadinya sindrom metabolik. Kadar kolesterol HDL yang rendah pada kondisi sindrom metabolik berhubungan dengan meningkatnya kadar trigliserida dalam darah. Sementara itu, kejadian hiperglikemia yang rendah pada penelitian ini $(8,8 \%)$ sesuai dengan kondisi yang terjadi pada remaja di wilayah Mediterania dalam penelitian tentang prevalensi sindrom metabolik. Penelitian tersebut menunjukkan bahwa hanya $0,6 \%$ remaja yang mengalami hiperglikemia (22).

Asupan makan menjadi salah satu faktor penentu terjadinya obesitas, yang kemudian dapat berlanjut menjadi sindrom metabolik. Asupan makan dalam jumlah berlebih yang berpotensi menyebabkan obesitas adalah asupan lemak dan karbohidrat karena keduanya akan disimpan di dalam tubuh pada sel-sel lemak jika dikonsumsi dalam jumlah yang melebihi kebutuhan. Penilaian konsumsi makanan pada penelitian ini digambarkan dalam skor kualitas diet. Hasil rerata skor kualitas diet remaja pada penelitian ini termasuk dalam kategori rendah $(48,04 \pm 7,82)$. Selain itu, persentase remaja yang memiliki kualitas diet rendah juga lebih banyak $(96,5 \%)$ dibandingkan dengan remaja yang memiliki kualitas diet tinggi (3,5\%). Kualitas diet yang rendah menunjukkan bahwa asupan makan seharihari pada remaja tidak bervariasi dan berlebih, serta menunjukkan konsumsi makanan secara keseluruhan tidak sesuai dengan rekomendasi gizi seimbang.

Secara lebih rinci, data asupan makanan menunjukkan bahwa subjek memiliki asupan lemak dan kolesterol yang berlebih serta asupan kalsium dan sayuran yang kurang. Selain itu, terdapat pula subjek dengan asupan natrium yang tinggi yaitu $2.956,4 \mathrm{mg} /$ hari (asupan rekomendasi $1500 \mathrm{mg} /$ hari). Hal ini terjadi karena remaja memiliki kegemaran makan snack yang tinggi natrium. Sebagian besar remaja mengonsumsi snack paling sedikit dua atau lebih snack per hari (25). Penelitian sebelumnya terhadap pola makan remaja umur 13-18 tahun di Saudi Arabia, menunjukkan bahwa $48,5 \%$ partisipan mengkonsumsi daging setiap harinya. Sementara untuk sayur, buah dan jus yang menjadi sumber serat dan mikronutrien masing-masing hanya $26,4 \% ; 27,6 \%$; dan $11,3 \%$ yang mengkonsumsinya setiap hari. Penelitian tersebut juga menyebutkan bahwa asupan tinggi lemak secara positif berhubungan dengan kejadian obesitas (26). Hal ini menunjukkan bahwa pola makan pada remaja tidak seimbang yaitu cenderung tinggi lemak dan natrium serta rendah serat.

Penelitian ini menunjukkan bahwa kelompok pra-sindrom metabolik memiliki kualitas diet, variasi, dan kecukupan diet, serta asupan serat yang lebih baik daripada kelompok sindrom metabolik. Asupan serat terutama dari buah dan sayur memang telah diketahui memiliki sifat proteksi terhadap beberapa komponen sindrom metabolik. Penelitian di Portugal tentang hubungan pola makan dan sindrom metabolik menunjukkan bahwa kelompok wanita dengan konsumsi rendah buah-buahan dan sayuran memiliki risiko lebih tinggi mengalami obesitas (27). Selain itu, uji korelasi skor kualitas diet dan jumlah faktor risiko juga menunjukkan korelasi negatif, yang berarti jika kualitas diet subjek tinggi maka faktor risiko SM yang dimiliki akan sedikit. Hal ini menunjukkan bahwa kualitas diet cukup mempengaruhi kejadian sindrom metabolik.

Uji korelasi antara komponen kualitas diet dengan komponen sindrom metabolik dilakukan untuk mengetahui komponen dalam kualitas diet yang menjadi pembeda antara subjek yang mengalami sindrom 
metabolik dan pra-sindrom metabolik. komponen variasi pada penelitian ini memiliki korelasi negatif dengan kadar trigliserida, yang berarti jika sumber makanan yang dikonsumsi semakin bervariasi maka kadar trigliserida dalam tubuh akan lebih baik dan menjadi normal. Selain itu, komponen kecukupan juga memiliki hubungan korelasi negatif dengan kadar trigliserida. Hasil ini sesuai dengan penelitian tentang healthy eating index pada kelompok remaja dan dewasa obesitas di US yang menyatakan bahwa variasi dan kecukupan konsumsi kelompok buah-buahan, biji-bijian, padi-padian, dan daging atau ikan memberikan pengaruh baik terhadap profil metabolik wanita obesitas (28). Variasi sumber makanan yang dikonsumsi memiliki pengaruh pada jenis karbohidrat dan lemak yang terdapat pada makanan yang diasup. Konsumsi minimal satu porsi makanan dari lima kelompok makanan (daging/unggas/ikan/ telur, susu/kacang-kacangan, biji-bijian, buah-buahan, dan sayuran) akan menurunkan tingkat kecenderungan asupan berlebihan dari salah satu golongan zat gizi saja (contohnya karbohidrat dan lemak). Dengan demikian, kadar trigliserida dalam tubuh tidak akan melebihi nilai normal sebab asupan karbohidrat dan lemak telah sesuai dengan anjuran.

\section{SIMPULAN}

Mayoritas remaja memiliki kualitas diet yang rendah (96,5\%), hanya 2 subjek yang memiliki kualitas diet yang tinggi. Berdasarkan hasil analisis dari lima komponen sindrom metabolik, ditemukan subjek yang mengalami obesitas abdominal (91,2\%); hipertligliseridemia (71,9\%); hipertensi $(61,4 \%)$; kadar HDL rendah (59,6\%); dan GDP tinggi (8,8\%). Jumlah subjek yang memiliki faktor risiko tersebut lebih besar terjadi pada remaja laki-laki dibanding perempuan. Sebagian besar subjek telah mengalami sindrom metabolik $(68,4 \%)$ dan sebagian mengalami pra-sindrom metabolik $(31,6 \%)$. Prevalensi sindrom metabolik pada remaja laki-laki $(69,2 \%)$ lebih tinggi daripada subjek perempuan $(67,7 \%)$. Kelompok pra-sindrom metabolik memiliki kualitas diet, variasi, kecukupan, dan asupan serat yang lebih tinggi dibandingkan dengan kelompok sindrom metabolik. Kualitas diet memiliki korelasi negatif dengan jumlah faktor risiko sindrom metabolik, meskipun tidak terdapat korelasi yang bermakna diantara keduanya. Selanjutnya, ada hubungan komponen variasi dan kecukupan dengan kadar trigliserida subjek.

\section{RUJUKAN}

1. Larsen PG, Adair LS, Popkin BM. The relationship of ethnicity, socioeconomic and overweight in U.S. adolescents. Obes Res 2003;11:121-9.

2. Badan Penelitian dan Pengembangan Kesehatan. Riset kesehatan dasar (Riskesdas 2013). Jakarta: Kementerian Kesehatan Republik Indonesia; 2013.

3. Badan Penelitian dan Pengembangan Kesehatan. Riset kesehatan dasar (Riskesdas 2010). Jakarta: Kementerian Kesehatan Republik Indonesia; 2010.

4. Duncan G, Li S, Xiao-hua Z. Prevalence and trends of a metabolic syndrome phenotype among U.S. adolescent, 1999-2000. Diabetes Care [series online] 2004 [cited 5 December 2014];27(10):2438-2443. Available online: URL: http://care.diabetesjournals.org/content/27/10/2438. full-text.pdf.

5. Cook S, Weitzman M, Auinger P, Nguyen M, Dietz WH. Prevalence of metabolic syndrome phenotype in adolescents: findings from the Third National Health and Nutrition Examination Survey, 1988-1994. Arch Pediatr Adolesc Med 2003;157(8):821-7.

6. Ryan D. Risk and benefits of weight loss: challenges to obesity research. Eur Heart J 2005; Supp7:L27-31.

7. Ma Y, Bertone ER, Stanek EJ, Reed GW, Hebert JR, Ockene IS. Association between eating pattern and obesity in free living US adult population. Am J Epidemiol 2003;158:85-92.

8. Daniels SR, Arnett DK, Eckel RH, Gidding SS. Overweight in children and adolescents, pathophysiology, consequence, prevention, and treatment. Circulation 2005;111:19992012.

9. Suryaputra K, Nadhiroh SR. Perbedaan pola makan dan aktivitas fisik antara remaja obesitas dengan non obesitas. Makara Kesehatan 2012;16(1):45-50.

10. Rosenheck R. Fast food consumption and increased caloric intake: a systematic review of a trajectory towards weight gain and obesity risk. Obes Rev 2008;9(6):535-47.

11. Malik VS, Schulze MB, Hu FB. Intake of sugar-sweetened beverages and weight gain: a systematic review. Am J Clin Nutr 2006;84:274-88.

12. Wolongevicz DM, Zhu L, Pencina MJ, Kimokoti RW, Newby PK, Millen BE. Diet quality and obesity in women: the Framingham Nutrition Studies. Br J Nutr 2010;103(8):1223-9. 
13. Family Nutrition Programs. Diet quality of Americans by food stamp participation status: data from the National Health and Nutrition Examination Survey, 1999-2004. [series online] 2008 [cited 21 November 2014]. Available online: URL: https://www.fns.usda.gov/sites/default/files/ NHANES-FSP.pdf

14. Dewi UP. Hubungan antara densitas energi dan kualitas diet dengan indeks massa tubuh (IMT) pada remaja. Journal of Nutrition College 2013;2(4):447-57.

15. Patterson E, Wärnberg J, Poortvliet E, Kearney JM, Sjöström M. Dietary energy density as a marker of dietary quality in Swedish children and adolescents: the European Youth Heart Study. Eur J Clin Nutr 2010;64(4):356-63.

16. Kementrian Kesehatan RI. Keputusan Menteri Kesehatan Republik Indonesia Nomor: 1995/Menkes/SK/XII/2010 tentang Standar antropometri penilaian status gizi anak. Jakarta: Kementerian Kesehatan RI Direktoral Jenderal Bina Gizi dan Kesehatan Ibu dan Anak; 2011.

17. Kim S, Haines PS, Siega-Riz AM, Popkin BM. The Diet Quality Index-International (DQI-I) provides an effective tool for cross-national comparison of diet quality as illustrated by China and the United States. J Nutr 2003;133(11):3476-84.

18. Tur JA, Romaguera D, Pons A. The Diet Quality IndexInternational (DQI-I): is it a useful tool to evaluate the quality of the Mediterranean diet?. Br J Nutr 2005;93(3):369-76.

19. Silveira LS, Buonani C, Monteiro PA, Moura Mello Antunes B, Junior IFF. Metabolic syndrome: criteria for diagnosing in children and adolescents. Endocrinol Metab Synd 2013;2(3):118.

20. Menteri Kesehatan Republik Indonesia. Peraturan Menteri Kesehatan Republik Indonesia Nomor 75 Tahun
2013 tentang Angka kecukupan gizi yang dianjurkan bagi bangsa Indonesia. Jakarta: Kementerian Kesehatan; 2013.

21. Pan Y, Pratt CA. Metabolic syndrome and its association with diet and physical activity in US adolescents. J Am Diet Assoc 2008;108:276-286.

22. Bibiloni MM, Martinez E, Llull R, Maffiotte E, Riesco M, Tur JA. Metabolic syndrome in adolescents in the Balearic Island, a Mediterranean region. Nutr Metab Cardiovasc Dis 2011;21(6):446-54.

23. Lee RD. Energy balance and body weight. In: Nelms M, Sucher KP, Lacey K, Roth SL. Nutrition therapy and patophysiology 2/e. Wadsworth: Cengage Learning, Inc.; 2010.

24. Rizzo AC, Goldberg TB, Silva CC, Kurokawa CS, Nunes HR, Corrente JE. Metabolic syndrome risk factors in overweight, obese, and extremely obese Brazilian adolescents. Nutr J 2013;12(19).

25. Sebastian RS, Cleveland LE, Goldman JD. Effect of snacking frequency on adolescents' dietary intakes and meeting national recommendations. J Adolesc Health 2008;42(5):503-11.

26. Washi SA, Ageib MB. Poor diet quality and food habits are related to impaired nutritional status in 13 to 18 years old adolescent in Jeddah. Nutr Res 2010;30(8):527-34.

27. Fonseca MJ, Gaio R, Lopes C, Santos AC. Association between dietary patterns and metabolic syndrome in a sample of Portuguese adults. Nutrition J 2012;11(64).

28. Camhi SM, Evans EW, Hayman LL, Lichtenstein AH, Must A. Healthy eating index and metabolically healthy obesity in U.S. adolescents and adults. Prev Med 2015;77:23-7. 